\title{
Seasonal abundance of equine strongyles (Nematoda: Strongylidae) in the State of Rio de Janeiro, Brazil
}

[Abundância sazonal de estrongilideos de eqüinos (Nematoda: Strongylidae) no Estado do Rio de Janeiro]

\author{
I.V.F. Martins ${ }^{1}$, M.J.S. Pereira ${ }^{2}$, L. Grisi $i^{2}$, F.B. Scott ${ }^{2}$ \\ ${ }^{1}$ Departamento de Zootecnia e Economia Rural - Universidade Federal do Espírito Santo \\ Alto Universitário s/n \\ 29500-000 - Alegre, ES \\ ${ }^{2}$ Instituto de Veterinária da UFRRJ -Seropédica - RJ
}

\begin{abstract}
The seasonal abundance of lumenal and larval forms of equine strongyles in the State of Rio de Janeiro, Brazil was evaluated. Thirty horses referred to the Federal Rural University of Rio de Janeiro were necropsied and their gastrointestinal tracts were separated into stomach, small intestine, cecum, ventral colon, dorsal colon and rectum. Two aliquots of $5 \%$ of the content were collected and examined for the presence of small strongyles and the rest of the content was examined for the presence of large strongyles. The mesenteric artery, liver, pancreas and peritoneum were examined for the presence of strongyle larvae. The mucosa of intestine segments was cut into parts of equal length, and each one was examined by the mural transillumination technique. Higher abundances of larvae of Strongylus equinus $(\mathrm{P}<0.10)$ and of adults Strongylus vulgaris $(\mathrm{P}<0.05)$ were observed during the dry season. Encysted cyathostome larvae had the highest abundance during the rainy season $(\mathrm{P}<0.02)$.
\end{abstract}

Keywords: strongyles, equine, abundance, season

\section{RESUMO}

Estudou-se a ocorrência sazonal de formas larvares e adultas de estrongilídeos nas mucosas do estômago, intestino delgado, ceco, colon ventral, colon dorsal e reto de 30 eqüídeos no Estado do Rio de Janeiro. Os grandes estrongilideos foram encontrados em todas as mucosas e duas alíquotas de 5\% do conteúdo foram retiradas para a procura de pequenos estrongilídeos. Artéria mesentérica, fígado, pâncreas e peritônio foram também examinados para larvas de estrongilídeos. As mucosas foram examinadas pela técnica de transiluminação. Larvas de Strongylus equinus $(P<0,10)$ e adultos de Strongylus vulgaris $(P<0,05)$ foram mais abundantes na estação seca. Larvas escistadas de ciatostomíneos o foram na estação chuvosa $(P<0,02)$.

Palavras-chave: estrongilídeos, eqüino, abundância, sazonalidade

\section{INTRODUCTION}

Infections caused by strongyles constitute a severe impediment to successful horse management due to debility and death of animals, particularly when heavy burdens are involved. Even light infections can affect the development and the performance of horses (Ogbourne, 1978).

The damage caused by large strongyles (Subfamily: Strongylinae) is well known. The

Recebido para publicação em 24 de setembro de 2003

Recebido para publicação, após modificações, em 28 de abril de 2004

E-mail: isabella@ufrrj.br 
adult worms produce lesions in the gut wall as they feed and larvae make destructive migrations in various tissues of the animal body. Strongylus vulgaris stands out as being particularly dangerous because the larvae develop in the mesenteric arterial system causing arteritis and thrombosis with serious consequences (Ogbourne and Duncan, 1985).

Reports on infections with cyathostomes have increased in recent years possibly due to some facts such as the increasing incidence of the problem, the recognition of a syndrome called larval cyathostomiasis and due to parasite resistance to the most modern anthelmintic drugs. In addition, the disease has been masked by severe effects of large strongyles, especially $S$. vulgaris, which are now uncommon due to effective control programs (Lyons et al., 2000).

Although healthy horses can carry large burdens of adult worms of cyathostomes with no prejudicial effects, infections with these worms, particularly at their larval stages, have increased as an important horse disease (Mair, 1994). Larval cyathostomiasis is related to the emergence of larvae from the mucosa or submucosa causing severe damage to the large intestine resulting diarrhea, colic, weight loss, ventral abdominal edema and even death (Lyons et al., 2000; Mair et al., 2000).

Many studies on strongyle infections in horses have been carried out in Brazil (Souto-Maior et al., 1995; Souto-Maior et al., 1999; Souto-Maior et al., 2000), but none of them evaluated the seasonal abundance of equine strongyles and only few studies have been reported on Cyathostominae species (Oliveira et al., 1994; Silva et al., 1995; Silva et al., 1999). The objective of this study was to evaluate the seasonal abundance of lumenal and larval forms of equine strongyles.

\section{MATERIALS AND METHODS}

From April 1998 to August 2000, 30 horses referred to the Federal Rural University of Rio de Janeiro were necropsied. The animals were naturally infected and had been kept for at least 6 months in the same pasture. Fifteen horses were necropsied during the dry season (May -
September) and 15 during the rainy season (October - April).

From each animal, the entire gastrointestinal tract was collected and mesenteric arteries were dissected for recovery of $S$. vulgaris larvae. The aorta artery was cut at the diaphragm and the cranial mesenteric artery and its branches were collected and identified for worm recovery. In the laboratory, mesenteric arteries were opened along their entire length. Liver and pancreas were also collected and cut into small parts and examined for the presence of larvae. The peritoneum was examined for the presence of strongyle larvae. All larval stages found were collected, counted and fixed in a solution of alcohol, formol and acetic acid (AFA) at $70^{\circ} \mathrm{C}$

For recovering adult worms, the gastrointestinal tract was examined isolating the different segments of the intestine. Each part of the intestine (small intestine, cecum, proximal ventral colon, distal ventral colon, proximal dorsal colon, distal dorsal colon and rectum) was kept in trays separately. Two aliquots of $5 \%$ of the content were taken and fixed in hot AFA and the rest of the content was examined for the presence of large strongyles, which were also fixed in hot AFA. The mucosas were washed and kept in labeled plastic bags.

In the laboratory, one aliquot of each segment was washed; the worms were collected and counted under a stereoscopic microscope and transferred to labeled bottles containing $70 \%$ alcohol. Nematodes were cleared in $90 \%$ phenol and identified using the keys and descriptions proposed by Lichtenfels (1975).

For counts of encysted cyathostome larvae, the large intestine segments were cut into parts of equal lengths $\left(16 \mathrm{~cm}^{2}\right)$ comprising $5 \%$ of the total segment weight, according to Reinemeyer and Herd (1986). The same methodology was used for the rectum and small intestine. All sections were kept in plastic bags and conserved in a refrigerator. Twenty-four hours later, the sections were examined by the mural transillumination technique using a stereoscopic microscope, as described by Eysker and Klei (1999), and the numbers of encysted larvae were recorded.

The Mann-Withney U test was used to compare abundances of adult and larval forms during the dry and the rainy season (Zar, 1999). 


\section{RESULTS AND DISCUSSION}

The values of mean abundances and statistical analysis are shown in Table 1 . S. equinus larvae and $S$. vulgaris adults were found with higher mean abundance during the dry season than that in the rainy season. The encysted cyathostome larvae had its highest mean abundance during the rainy season.

Table 1. Mean abundance of values analised by $U$ of Mann-Whitney test between larvae abundance and adult abundance equine strongyles in the rainy and dry season

\begin{tabular}{|c|c|c|c|c|}
\hline \multirow{2}{*}{ Strongyles } & \multicolumn{2}{|c|}{ Mean abundance $( \pm \mathrm{SD})$} & \multirow{2}{*}{$Z c$} & \multirow{2}{*}{$P$ value } \\
\hline & Dry season & Rainy season & & \\
\hline Strongylus equinus & $5.4 \pm 8.7$ & $2.0 \pm 4.3$ & -1.224 & 0.220 \\
\hline S. equinus larvae & $2.6 \pm 3.8$ & $0.6 \pm 1.4$ & -1.688 & $0.091 *$ \\
\hline Strongylus vulgaris & $76.1 \pm 86.0$ & $10.8 \pm 20.1$ & -1.990 & $0.046^{* *}$ \\
\hline Strongylus vulgaris larvae & $36.5 \pm 56.1$ & $40.4 \pm 68.6$ & -0.768 & 0.442 \\
\hline Strongylus edentatus & $51.3 \pm 66.0$ & $25.0 \pm 35.0$ & -1.156 & 0.247 \\
\hline Strongylus edentatus larvae & $3.8 \pm 6.8$ & $0.8 \pm 1.8$ & -1.582 & 0.113 \\
\hline Triodontophorus spp. & $28.2 \pm 87.0$ & $140.4 \pm 475.3$ & -0.374 & 0.707 \\
\hline Lumenal Cyathostomes & $115,336.0 \pm 80,212.3$ & $89,245.3 \pm 69.315,3$ & -0.891 & 0.372 \\
\hline Encysted Cyathostomes & $21,590.6 \pm 17,178.6$ & $65,578.6 \pm 89,516.6$ & -2.509 & $0.012 * * *$ \\
\hline
\end{tabular}

$\mathrm{SD}=$ standard deviation.

In a study carried out on epidemiological aspects of bovine gastrointestinal nematodes in Central Brazil, Bianchin (1991) concluded that the number of infective larvae on pasture was higher during the rainy season, although the conditions for the development of larvae were appropriate throughout the year. As far as equine strongyles are concerned, Rodrigues (1989) observed that transmission occurs throughout the year in Rio de Janeiro, Brazil, and that the highest larval development is observed during the summer (rainy season), although larval survival was higher during the dry season.

In tropical Australia, Mfitilodze and Hutchinson (1990) recorded the highest mean abundance of equine strongyles during the dry season (September - November) and the lowest numbers of parasites during the rainy season (December - February). Higher worm burdens of other species have also been described during dry season, similarly to the present study, in which the highest mean abundance of strongyle species was observed during the dry season.

Souto-Maior et al. (1995) observed higher means of $S$. vulgaris larvae during the rainy season, and Rodrigues (1989) recorded infective $S$. vulgaris larvae mostly in May and June (dry season in Brazil). In this period, lower numbers of migrating larvae are seem in the mesenteric arteries, but higher numbers of adults are found in the intestines.

Regarding encysted cyathostome larvae, Eysker and Pandey (1989), in Zimbabwe, recorded that even though encysted larvae develop mostly in the winter time (dry season), the worm burdens did not decrease from December to April. The same authors verified the capacity of larval development in the summertime (rainy season). In temperate climates the larval stages are found during the winter, as reported in England (Ogbourne, 1976; 1978) and in The Netherlands (Eysker et al., 1984, 1990), although it is known that in these countries, rainfalls are unchangeable all year long.

Krecek et al. (1987) studied 25 zebras in South Africa and found that infections of 11 cyathostome species were significantly more intense during fall/winter (dry season). In Australia, Bucknell et al. (1995) observed that infections of cyathostome species in the lumen were more prevalent and more intense in rainfall areas and that the mean intensity of Cyathostominae subfamily was higher in areas of intense rains. However, Dunsmore and Jue Sue (1985) found lumenal stages throughout the year in Western Australia. 


\section{CONCLUSIONS}

The knowledge of a seasonal effect on equine strongyle infections may contribute to the development of strategic control programs for horse farms in Rio de Janeiro, Brazil. During the dry season (May - September) horses maintain the highest worm burdens and anthelmintics treatments may be considered. The selection of an anthelmintic base able to remove encysted cyathostome larvae at the end of the rainy season could decrease the number of worms that will develop into adult stages. This would contribute to decrease levels of pasture contamination in the subsequent rainy season.

\section{REFERENCES}

ANJOS, D.H.S. Estrutura das infracomunidades de estrongilídeos (Nematoda: Strongylidae) do cólon dorsal de Equus caballus naturalmente infectados, proveniente da Região Metropolitana do Rio de Janeiro. Rio de Janeiro: UFRRJ, 1998. 62f. Dissertação (Mestrado) - Universidade Federal Rural do Rio de Janeiro, Rio de Janeiro.

BIANCHIN, I. Epidemiologia e controle de helmintos gastrintestinais em bezerros a partir da desmama, em pastagem melhorada, em clima tropical do Brasil. 1991. 162f. Tese (Doutorado) - Universidade Federal Rural do Rio de Janeiro, Rio de Janeiro.

BUCKNELL, D.G.; GRASSER, R.B.; BEVERIDGE, I. The prevalence and epidemiology of gastrointestinal parasites of horses in Victoria, Australia. Int. J. Parasitol., v.25, p.711-724, 1995.

DUNSMORE, J.D.; JUE SUE, L.P. Prevalence and epidemiology of the major gastrointestinal parasites of horses in Perth, Western Australia. Equine Vet. J., v.17, p.208-213, 1985.

EYSKER, M.; BOERSEMA, J.H.; KOOYMAN, F.N. Seasonally inhibited development of cyathostominae nematodes in Shetland ponies in the Netherlands. Vet. Parasitol., v.36, p.259-264, 1990.

EYSKER, M.; JANSEN, J.; MIRCK, M.H. Inhibited development of Cyathostominae in the horse in the early third stage. Res. Vet. Sci., v.37, p.355-356, 1984.
EYSKER, M.; KLEI, T.R. Mucosal larval techniques of cyathostomes: can they be standardized? Vet. Parasitol., v.85, p.137-149, 1999.

EYSKER, M.; PANDEY, V.S. Small Strongyle infection in donkeys from the Highveld of Zimbabwe. Vet. Parasitol., v.30, p.345-349, 1989.

KRECEK, R.C.; MALAN, F.S.; REINECKE, R.K. et al. Nematodes parasites from Burchell's zebras in South Africa. J. Wildlife Dis., v.23, p.404-411, 1987.

LICHTENFELS, J.R. Helminths of domestic equids. Illustrated keys to genera and species with emphasis on the North American forms. Proc. Helm. Soc. Wash., v.42, p.1-92, 1975.

LYONS, E.T., DRUDGE, J.H., TOLLIVER, S.C. Larval cyathostomiasis. Vet. Clin. North Am.: Equine Pract., v.16, p.501-513, 2000.

MAIR, T.S. Outbreak of larval cyathostomiasis among a group of yearling and two-year-old horses. Vet. Rec., v.135, p.598-600, 1994.

MAIR, T.S.; SUTTON, D.G.; LOVE, S. Caecocaecal and caecocolic intussusceptions associated with larval cyathostomosis in four young horses. Equine Vet. J., v.32, p.77-80, 2000 .

MFITLODZE, M.W.; HUTCHINSON, G.W. Prevalence and abundance of equine strongyles (Nematoda: Strongyloidea) in tropical Australia. J. Parasitol., v.76, p.487-494, 1990.

OGBOURNE, C.P. Pathogenesis of cyathostome (Trichonema) infection of the horse. A review. Comm. Inst. Helmint., Comm. Agric. Bureaux, Farnham Royal Slough. Miscellaneous publication $\mathrm{n}^{\circ} 5$, 1978. 25p.

OGBOURNE, C.P. The prevalence, relative abundance and site distribution of nematodes of the subfamily Cyathostominae in horses killed in Britain. J. Helminthol., v.50, p.203-214, 1976.

OGBOURNE, C.P.; DUNCAN, J.L. Strongylus vulgaris in the horse: its biology and veterinary importance. 2. Comm. Inst. Parasitol., Comm. Agric. Bureaux, Farnham Royal Slough. SL2 3BN United Kingdom, 1985.

OLIVEIRA, C.L.; SILVA, A.V.M.; SANTOS, H.A. et al. Cyathostominae parasite of Equus 
asinus L. in some Brazilian States. Arq. Bras. Med. Vet. Zootec., v.46, p.51-63, 1994.

REINEMEYER, C.R.; HERD, R.P. Anatomic distribution of cyathostome larvae in the horse. Am. J. Vet. Res., v.47, p.510-513, 1986.

RODRIGUES, M.L.A. Sobrevivência de ovos e de larvas infectantes de nematóides (Nematoda: Strongylidae), em eqüinos, nas pastagens e nas fezes. 1989. 83f. Tese (Doutorado) Universidade Federal Rural do Rio de Janeiro, Rio de Janeiro.

SILVA, A.V.M.; COSTA, H.M.A.; SANTOS, H.A. et al. Cyathostominae (Nematoda) parasite of Equus caballus L. in some Brazilian States. Vet. Parasitol., v.86, p.15-21, 1999.

SILVA, A.V.M.; SANTOS, H.A.; COSTA, H.M.A. Cyathostominae (Nematoda: Strongylida) encontrados em mulas de alguns estados de Brasil. Rev. Med. Vet., v.76, p.124129, 1995.
SOUTO MAIOR, M.P.; RODRIGUES, M.L.A.; ANJOS, D.H.S. et al. Estrutura das infracomunidades de nematóides estrongilídeos (Nematoda: Strongylidae) do ceco de Equus caballus naturalmente infectados, provenientes da região metropolitana do Rio de Janeiro, Brasil. Parasitol. al dia, v.23, p.24-32, 1999.

SOUTO MAIOR, M.P.; CARVALHO JUNIOR, G.M.; BARBOSA, C.L. Prevalência e intensidade de infecção de formas imaturas de Strongylus vulgaris (Nematoda: Strongylidae) na região metropolitana do Rio de Janeiro - Brasil (observações preliminares). Rev. Bras. Med. Vet., v.17, p.179-182, 1995.

SOUTO MAIOR, M.P.; RODRIGUES, M.L.A.; BARBOSA, C.L. Helminthic fauna of the dorsal colon of equids from the Pernambuco State, Brazil. Parasitol. dia, v.24, p.60-62, 2000.

ZAR, J.H. Biostatistical analysis. New Jersey: Prentice. Hall, 1999. 663p. 